DOI: https://doi.org/10.47405/mjssh.v5i11.525

\begin{tabular}{|c|c|}
\hline$\sqrt{15}$ & Malaysian Journal of Social Sciences and Humanities (MJSSH) \\
\hline Malaysian Journal of & Volume5, Issue 11, November 2020 \\
\hline $\begin{array}{l}\text { Humanities } \\
\text { (MJ-ssH) }\end{array}$ & e-ISSN : 2504-8562 \\
\hline & $\begin{array}{l}\text { Journal home page: } \\
\text { www.msocialsciences.com }\end{array}$ \\
\hline
\end{tabular}

\title{
Model Kebahagiaan Hidup Pelajar Universiti Berdasarkan Faktor Kesihatan Mental, Kecerdasan Spiritual dan Demografi
}

\author{
Muhammad Salehan Alhafiz Mat Wajar 1, Rohana Hamzah1 \\ 1Universiti Malaysia Pahang (UMP)
}

Correspondence: Muhammad Salehan Alhafiz (muhammadsalehanalhafiz@gmail.com)

\begin{abstract}
Abstrak
Kebahagiaan hidup merupakan salah satu faktor yang boleh memberi kesan ke atas prestasi akademik pelajar. Sorotan kajian lepas mendapati bahawa antara faktor penyumbang utama kepada kebahagiaan hidup pelajar ialah kesihatan mental dan kecerdasan spiritual. Tahap kebahagiaan hidup juga berbeza bagi setiap pelajar bergantung kepada faktor demografi mereka. Walau bagaimanapun, kajian lanjutan perlu dijalankan bagi mengenal pasti sejauh mana kesihatan mental dan kecerdasan spiritual boleh mempengaruhi kebahagiaan hidup dan prestasi akademik dalam konteks pelajar universiti di Malaysia. Kajian mengenai pengaruh faktor demografi seperti jantina, tahun pengajian dan agama terhadap tahap kebahagiaan hidup pelajar juga masih belum diterokai sepenuhnya. Oleh itu, artikel ini bertujuan untuk membangunkan sebuah model konseptual kebahagiaan hidup pelajar daripada aspek kesihatan mental, kecerdasan spiritual dan demografi berdasarkan sorotan kajian lepas dan teori-teori berkaitan seperti Teori Psikologi Positif Seligman (2003), Teori Kecerdasan Spiritual Amram (2008) dan Teori Kesejahteraan Subjektif Diener (1984). Model yang dibangunkan ini boleh dijadikan rujukan untuk mengkaji hubungan antara kesihatan mental, kecerdasan spiritual dan demografi dengan kebahagiaan hidup dan prestasi akademik pelajar universiti di negara ini.
\end{abstract}

Kata kunci: kesihatan mental, kecerdasan spiritual, demografi, kebahagiaan hidup, prestasi akademik

\section{The Life Happiness Model for University Students Based on Mental Health, Spiritual Intelligence and Demography Factors}

\begin{abstract}
Life happiness is one of the influential factors that have an impact on students' academic performance. Previous studies had shown that among the main factors contributing to students' life happiness are mental health and spiritual intelligence. The level of life happiness also differs for every student depending on their demographic factors. However, further research needs to be carried out to understand the influence of mental health and spiritual intelligence on life happiness and academic performance in the context of university students in Malaysia. Research on the impact of gender, year of study and religion on students' life happiness has also not yet been explored. Therefore, this article aims to develop a conceptual model of students' life happiness based on mental health, spiritual intelligence and demographic factors derived from the findings of previous studies and related theories such as Seligman's Positive Psychology Theory (2003), Amram's Spiritual Intelligence Theory (2008) dan Diener's Subjective Well-Being Theory (1984). The model may be used as a reference to investigate the influence of mental health, spiritual intelligence and demographic factors on life happiness and academic performance of university students in this country.
\end{abstract}


Keywords: mental health, spiritual intelligence, demography, life happiness, academic performance

\section{Pengenalan}

Era globalisasi dan proses urbanisasi menjadikan kehidupan masyarakat masa kini menjadi semakin kompleks berikutan perubahan sosial, budaya dan ekonomi. Perubahan-perubahan ini telah mewujudkan tekanan yang turut memberi implikasi yang sangat besar kepada kesejahteraan dan kebahagiaan manusia sejagat, terutamanya daripada aspek kesihatan mental dan spiritual.

Golongan muda terutamanya pelajar-pelajar yang sedang menuntut di institut pengajian tinggi (IPT) turut menerima tempias daripada gelombang perubahan psikososial ini dan terpaksa berdepan dengan pelbagai cabaran dan tekanan dalam menyesuaikan diri dengan perubahan-perubahan yang berlaku. Dalam masa yang sama, mereka perlu memastikan kecemerlangan akademik bagi menyiapkan diri untuk kerjaya profesional. Secara tidak langsung, golongan ini sangat cenderung untuk mengalami tekanan sehingga boleh menjejaskan tahap kesihatan fizikal, mental, emosi dan spiritual (Pfeiffer, 2001; Samsudin \& Tan, 2016; Hoo, 2008) dan seterusnya memberi kesan negatif ke atas tahap kebahagiaan hidup mereka (Aghili, 2012; Salehi et al., 2011; Jalilian et al., 2017; Ebadi et al., 2016; Jamali \& Abasi, 2013; Mozafarinia et al., 2014).

Banyak kajian lepas telah membuktikan bahawa kebahagiaan hidup pelajar merupakan satu faktor penting bagi memastikan kecemerlangan dalam akademik. Kajian yang dijalankan oleh Hassanzadeh dan Mahdinejad (2013) di Iran dan Schiller dan Hinton (2015) di Amerika Syarikat misalnya mendapati bahawa terdapat hubungan yang signifikan antara kebahagiaan dan pencapaian akademik dan motivasi pelajar. Kajian oleh Tabbodi et al. (2015) ke atas 320 orang pelajar di Islamic Azad University of Shiraz mendapati kebahagiaan hidup mempunyai hubungan yang signifikan dan positif dengan prestasi akademik. Begitu juga dengan Wilcox dan Nordstokke (2019) yang menemukan korelasi yang positif dan signifikan antara kesejahteraan hidup di kolej dan pencapaian akademik di kalangan pelajar di University of Calgary.

Kesemua dapatan kajian ini menyokong pernyataan Pertubuhan Kesihatan Dunia (WHO) di mana individu yang sentiasa berada dalam keadaan gembira, bahagia serta kerap merasai emosi positif mampu mengenal pasti kebolehan, kemahiran dan keupayaan diri sendiri serta boleh bertindak balas dengan tekanan kehidupan atau perubahan persekitaran dengan lebih baik (WHO, 2001). Pelajar yang mempunyai tahap kebahagiaan hidup yang tinggi juga dilihat kurang terlibat dalam perilaku sosial yang negatif seperti ponteng, tidak hadir kelas dan masalah-masalah disiplin yang lain (Byrk \& Driscoll, 1998; Lyubomirsky et al., 2005).

Sorotan kajian lepas telah mendapati bahawa antara faktor penyumbang kepada kebahagiaan hidup seseorang pelajar adalah kesihatan mental (Aghili, 2012; Salehi et al., 2011; Kamkary \& Shokrzady, 2012; Shafiq et al., 2015; Mostafai, 2012; Sasanpour et al., 2012; Abdel-Khalek, 2006) dan kecerdasan spiritual (Jalilian et al., 2017; Ebadi et al., 2016; Jamali \& Abasi, 2013; Mozafarinia et al., 2014; Francis et al., 2015). Tahap kebahagiaan hidup juga berbeza bagi setiap individu bergantung kepada faktor demografi seperti jantina dan umur (Hill, 2015; Turashvili \& Japaridze, 2012; Tabbodi et al., 2015).

Walaubagaimanapun, masih kurang kajian yang memfokuskan kepada pengaruh kesihatan mental, kecerdasan spiritual dan demografi ke atas kebahagiaan hidup pelajar dan prestasi akademik terutamanya dalam konteks universiti di Malaysia. Tambahan pula, kajian lepas juga mendapati bahawa masalah kesihatan mental dan spiritual di kalangan pelajar di Malaysia semakin meningkat setiap tahun dan perlu diberi perhatian dengan sewajarnya (Samsudin \& Tan, 2016, 2016: Zulkefly \& Baharudin, 2010; Hoo, 2008; Norazwa, 2013; Rosidi, 2017; Ismail, Anwar \& Hamsan, 2010). 
DOI: https://doi.org/10.47405/mjssh.v5i11.525

Dengan erti kata lain, terdapat kepentingan untuk melaksanakan kajian yang lebih mendalam untuk memahami situasi kesihatan mental dan kecerdasan spiritual pelajar-pelajar universiti di negara ini. Seterusnya kajian ini diharapkan dapat membangunkan sebuah model bagi mengkaji bagaimana faktorfaktor ini boleh mempengaruhi kebahagiaan hidup dan prestasi akademik pelajar.

\section{Sorotan Literatur}

\section{Definisi \& Konsep Kebahagiaan Hidup}

Menurut Kamus Dewan Bahasa Edisi Keempat, kebahagiaan (happiness) ialah keadaan hidup yang aman damai serta gembira. Istilah kebahagiaan juga seringkali dikaitkan kesejahteraan subjektif iaitu bagaimana seseorang menilai sama ada kehidupannya baik (good life) dan menyenangkan (pleasant life) (Seligman \& Royzman, 2003). Penilaian ini termasuklah penilaian kognitif (pemikiran) seperti kepuasan hidup, dan perasaan (mood dan emosi) seperti emosi yang bersifat negatif dan positif (Eddington \& Shuman, 2005).

Dalam kajian mengenai kebahagiaan masyarakat Melayu, Tak (2017) menyenaraikan 12 dimensi kebahagiaan hidup iaitu hubungan kekeluargaan, autonomi, agama, sikap positif, hubungan dengan orang lain, ilmu pengetahuan, penerimaan takdir, persekitaran harmoni, aktiviti masa lapang, taraf hidup, kesihatan dan pencapaian hidup (rujuk Rajah 1).

Rajah 1: Dimensi kebahagiaan hidup masyarakat Melayu

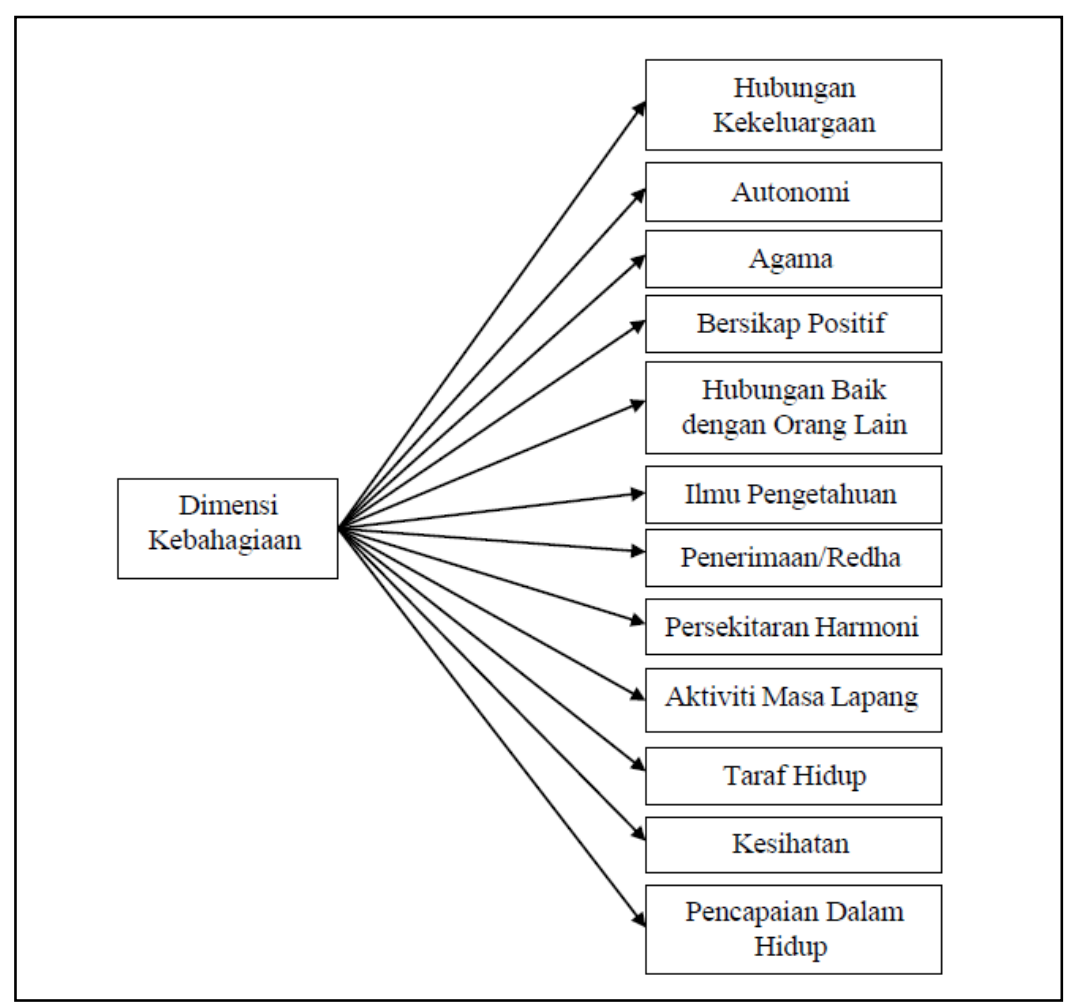

Sumber: Tak (2017)

Berdasarkan kepada keterangan di atas, istilah kebahagiaan hidup dalam kajian ini boleh didefinisikan sebagai penafsiran pelajar mengenai kualiti kehidupan mereka daripada aspek kognitif seperti tahap kepuasan terhadap hubungan dengan keluarga, hubungan dengan rakan, hubungan dengan tenaga pengajar, pembelajaran, pengurusan masa, persekitaran akademik, tahap kesihatan dan tahap kewangan, serta dari aspek emosi seperti perasaan dan mood yang dirasai sepanjang tempoh pengajian mereka di universiti. 


\section{Faktor Pendorong Kebahagiaan Hidup}

Sorotan kajian lepas telah mendapati bahawa faktor-faktor yang mendorong kepada kebahagiaan hidup seseorang pelajar terbahagi kepada faktor luaran dan faktor dalaman (rujuk Rajah 2).

Rajah 2: Faktor Dalaman dan Luaran Kebahagiaan Hidup

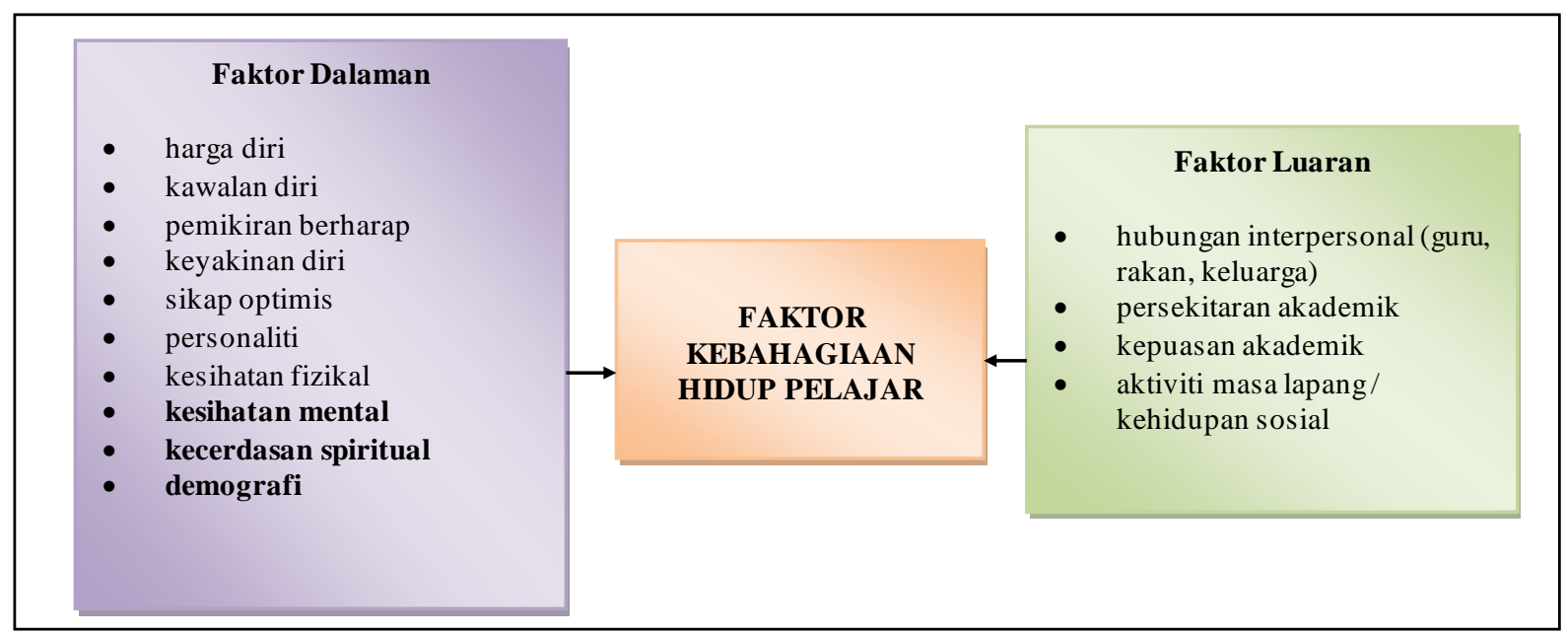

Faktor dalaman adalah seperti harga diri (self-esteem), kawalan diri (self-control), pemikiran berharap (hopeful thinking), keyakinan diri dan sikap optimis (Huebner, 2010; Hill, 2015; Diener et al., 2009; Schimmack \& Diener, 2003). Selain itu, tahap kebahagiaan dan kepuasan hidup pelajar juga boleh dipengaruhi oleh ciri-ciri personaliti di mana pelajar berpersonaliti ekstrovert dilihat lebih cenderung untuk terlibat dalam kegiatan atau perilaku yang boleh merangsang kebahagiaan atau happiness inducing behaviors (HIB) seperti berhibur, bersukan, bersosial dan sebagainya, manakala pelajar yang berpersonaliti neurotik cenderung untuk mempamerkan emosi negatif seperti stress, ketakutan, marah dan rasa bersalah (Albuquerque et al., 2013; Senf \& Liau, 2013; Kirkpatrick, 2015).

Terdapat juga beberapa faktor dalaman lain yang boleh mempunyai pengaruh yang signifikan terhadap kebahagiaan hidup seseorang pelajar seperti faktor kesihatan fizikal (Compton, 2005; Pierewan \& Tampubolon, 2014; Zajacova \& Dowd, 2014), faktor kesihatan mental (Abdel-Khalek, 2006), faktor agama atau spiritual (Ngamaba \& Soni, 2017; Jung, 2014; Sahraian et al., 2013) dan faktor demografi individu (Hill, 2015; Tabbodi et al., 2015). Walaubagaimanapun, artikel ini hanya akan menghuraikan dengan lebih lanjut mengenai tiga faktor dalaman iaitu kesihatan mental, kecerdasan spiritual dan demografi.

Faktor luaran pula adalah seperti hubungan interpersonal dengan ahli keluarga, rakan dan guru, persekitaran akademik dan kepuasan akademik. Pelajar yang mempunyai hubungan interpersonal yang positif dengan rakan kolej dan pensyarah dilihat cenderung untuk mempamerkan tahap kebahagiaan hidup yang tinggi (Huebner, 2010; Jones, 2015; Borgonovi, 2015). Mereka yang berpuas hati dengan kualiti pembelajaran, persekitaran akademik, pengurusan masa, kehidupan sosial dan pencapaian akademik di universiti juga lebih cenderung untuk berasa lebih gembira sepanjang pengajian mereka di universiti (Jones, 2015; Huebner, 2010; Zulkifli, 2013). Kajian oleh Liang et al. (2013), Nawijn dan Veenhoven (2011), Pagán (2014) dan Rodri'guez et al. (2008) pula mendapati bahawa aktiviti masa lapang seperti mendengar muzik, melancong, menonton televisyen dsb. berupaya menghilangkan tekanan dan memberikan keseronokan dan kebahagiaan.

\section{Definisi dan Konsep Kesihatan Mental}

Kesihatan mental merujuk kepada suatu keadaan kesejahteraan di mana seseorang individu menyedari kebolehan mereka sendiri, dapat menghadapi tekanan normal kehidupan, boleh bekerja secara produktif dan mampu menyumbang kepada masyarakat (WHO, 2007). Kesihatan mental juga ialah 
suatu keadaan di mana seseorang individu boleh mengawal selia emosi dan kognitifnya dan berkait rapat dengan fikiran, perasaan dan tindakannya apabila berada dalam pelbagai situasi dan berdepan dengan pelbagai tekanan (WHO, 2001).

Menurut Yusoff (2010), kesihatan mental pelajar boleh diukur berdasarkan tujuh dimensi iaitu Stress, Masalah Keyakinan Diri, Kebimbangan dan Kemurungan, Konflik Interpersonal, Gangguan Tidur, Penggunaan Alkohol dan Dadah, dan Gangguan Fokus Akademik (rujuk Rajah 3). Dengan kata lain, kesihatan mental merujuk kepada keadaan minda pelajar dalam menyelia emosi, kognitif dan tindakannya apabila berdepan dengan isu tekanan akademik, keyakinan diri, konflik interpersonal, jiwa dalaman dan tekanan sosial yang boleh mengganggu fokus dan kehidupan mereka sebagai pelajar di universiti.

Rajah 3: Dimensi Kesihatan Mental

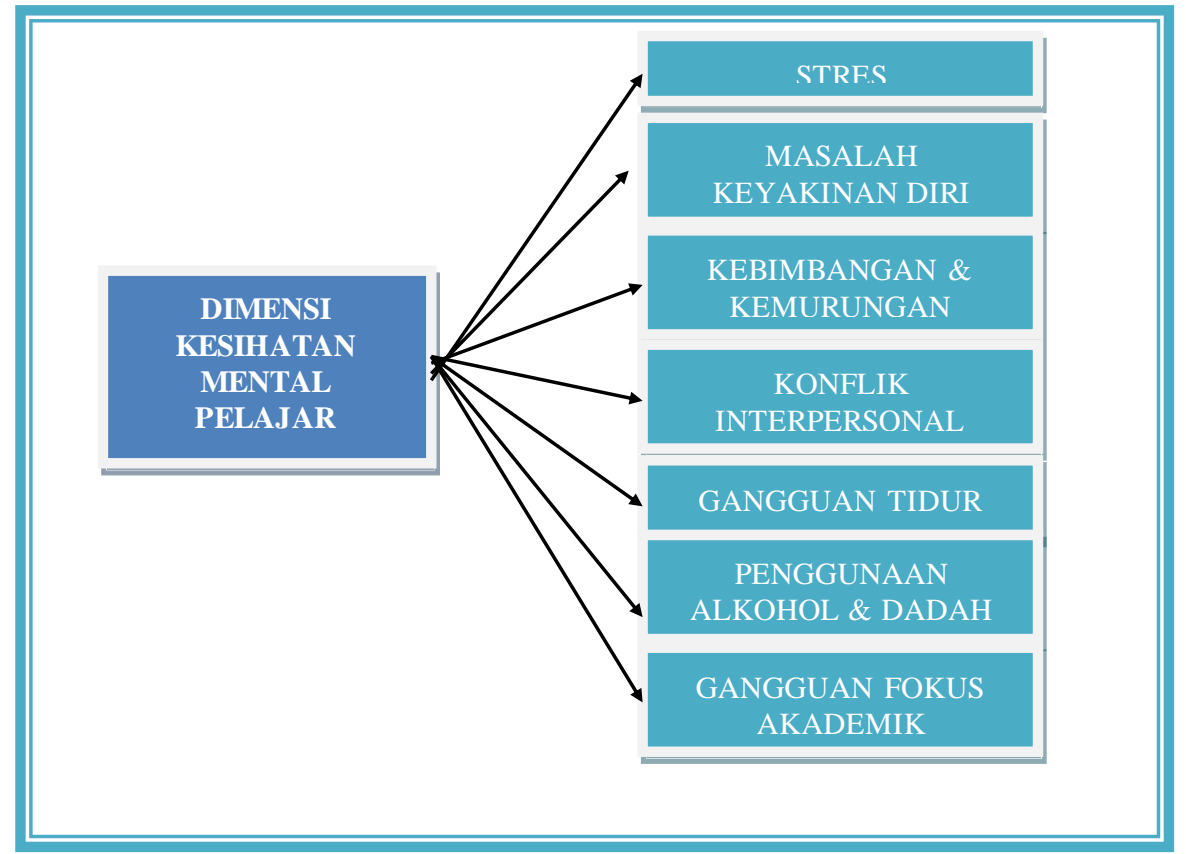

Sumber: Yusoff (2010)

Berdasarkan pengertian di atas, kesihatan mental dalam kajian ini merujuk kepada keupayaan pelajar untuk berdaya tindak terhadap stres, masalah keyakinan diri, kebimbangan dan kemurungan, konflik interpersonal, gangguan tidur, gangguan fungsi sosial dan gangguan fokus akademik sepanjang tempoh pengajian mereka di universiti.

\section{Faktor Pendorong Kesihatan Mental}

Sorotan kajian lepas telah mendapati terdapat beberapa faktor yang boleh mendorong kepada kesihatan mental seseorang pelajar. Antara faktor yang dikenalpasti melalui sorotan kajian dirumuskan dalam Rajah 4.

Dalam konteks pelajar universiti, antara faktor yang boleh mempengaruhi tahap kesihatan mental pelajar termasuk faktor perubahan psikososial dan tekanan akademik. Ini adalah kerana pelajar perlu menyesuaikan diri terhadap perubahan-perubahan psikososial yang berlaku sepanjang tempoh pengajian bagi menyiapkan diri mereka untuk kerjaya profesional yang lebih mencabar (Uehara et al. 2010). Secara tidak langsung, mereka cenderung untuk berasa tertekan sehingga boleh menjejaskan kesihatan fizikal dan mental mereka (Pfeiffer 2001; Samsudin \& Tan, 2016; Desa \& Sulaiman, 2004). 


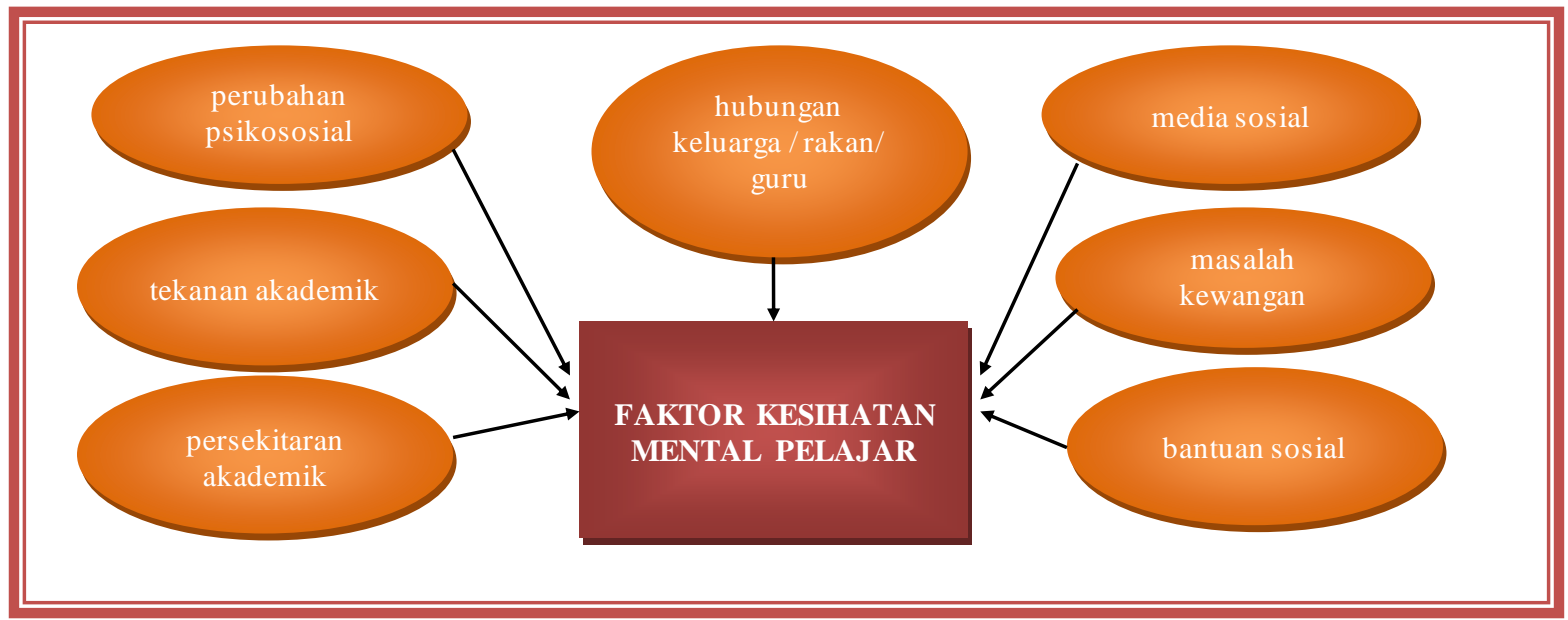

Faktor-faktor lain yang juga boleh mempengaruhi tahap kesihatan mental pelajar termasuk persekitaran akademik dan hubungan keluarga (Hoo, 2008; Sherina et al., 2003; Hamid \& Rhouse, 2005, penggunaan media sosial (Yvonne et al., 2018), pencapaian akademik (Yahaya et al., 2005), konflik dan gangguan rakan sebaya (Hamid \& Rhouse, 2005; Dusselier et al., 2005), tekanan kewangan (Lee \& Syaid, 2018; Hyun et al., 2006; Adams \& Moore, 2007) dan kekurangan bantuan sosial (Hefner \& Eisenberg, 2009). Kesemua faktor ini dilihat boleh menjejaskan kesihatan mental pelajar dan menyebabkan mereka terdedah kepada pelbagai masalah berkaitan psikologi seperti skizophrenia, depresi, stres, gangguan pemakanan, gangguan tidur, masalah ketagihan alkohol dan penyalahgunaan dadah.

\section{Kesihatan Mental - Kebahagiaan Hidup}

Banyak kajian lepas telah menunjukkan hubungan yang signifikan dan positif antara kesihatan mental dan kebahagiaan hidup. Kajian yang dijalankan oleh Aghili (2012) di Iran misalnya merumuskan bahawa belia yang mempunyai tahap kesihatan mental yang baik lebih cenderung untuk rasa gembira dengan kehidupan mereka. Salehi, Hajizad dan Bagheri (2011) pula mendapati bahawa terdapat korelasi antara pegangan agama, kesejahteraan mental dan kebahagiaan hidup di kalangan 385 orang pelajar Islamic Azad University di Mazandaran, Pakistan. Kamkary dan Shokrzadeh (2012) dalam kajian mereka ke atas 1000 orang belia di Tehran menemukan hubungan yang positif antara kesihatan mental dan kebahagiaan hidup. Begitu juga kajian yang dijalankan oleh Sameera Shafiq et al. (2015), Mostafai (2012), Sasanpour, Khodabakhshi dan Nooryan (2012), dan Abdel-Khalek (2006).

Walaupun dapatan kajian-kajian di atas merumuskan bahawa kesihatan mental boleh mempengaruhi kebahagiaan hidup pelajar, kajian lanjutan perlu dibuat untuk mengenalpasti sejauh mana dan bagaimana hubungan di antara dua faktor ini dalam konteks pelajar universiti di Malaysia. Oleh itu, model kajian yang dibangunkan akan mengambil kira pengaruh kesihatan mental ke atas kebahagiaan hidup pelajar.

\section{Definisi dan Konsep Kecerdasan Spiritual}

Spiritual merujuk kepada segala sesuatu di luar fizikal tubuh termasuk fikiran, perasaan dan karakter seseorang (Kurniawati \& Abrori, 2005). Menurut Subandi (2000), kecerdasan spiritual ialah keupayaan individu untuk membersihkan jiwa dari pengaruh negatif. Fisher (2010) pula menggambarkan kesejahteraan spiritual sebagai kehidupan individu yang harmoni dan mempunyai nilai, makna dan tujuan hidup. Vaughan (2002) merujuk kesejahteraan spiritual kepada hubungan yang harmoni di antara seorang manusia dengan penciptanya iaitu Tuhan, manusia lain dan alam sekitar. Zohar dan Marshall (2001) mendefinisikan kecerdasan spiritual sebagai kecerdasan individu untuk menghadapi dan memecahkan persoalan makna dan nilai hidup, iaitu meletakkan perilaku dan hidupnya dalam 
konteks makna yang lebih luas, dan keupayaan untuk menilai bahawa tindakan dan jalan hidupnya lebih bermakna dibandingkan dengan yang lain.

Merujuk kepada makna-makna di atas, Ashshidieqy (2018) seterusnya mengembangkan konsep kecerdasan spiritual dalam konteks agama Islam iaitu keupayaan seseorang individu Muslim untuk membersihkan jiwa daripada pengaruh negatif dengan memiliki tujuan hidup yang baik, memiliki prinsip hidup, merasakan kehadiran penciptanya (Allah), melakukan amalan kebaikan, memiliki jiwa besar dan memiliki empati (rujuk Rajah 5).

Rajah 5: Ciri-ciri Kecerdasan Spiritual dalam Islam

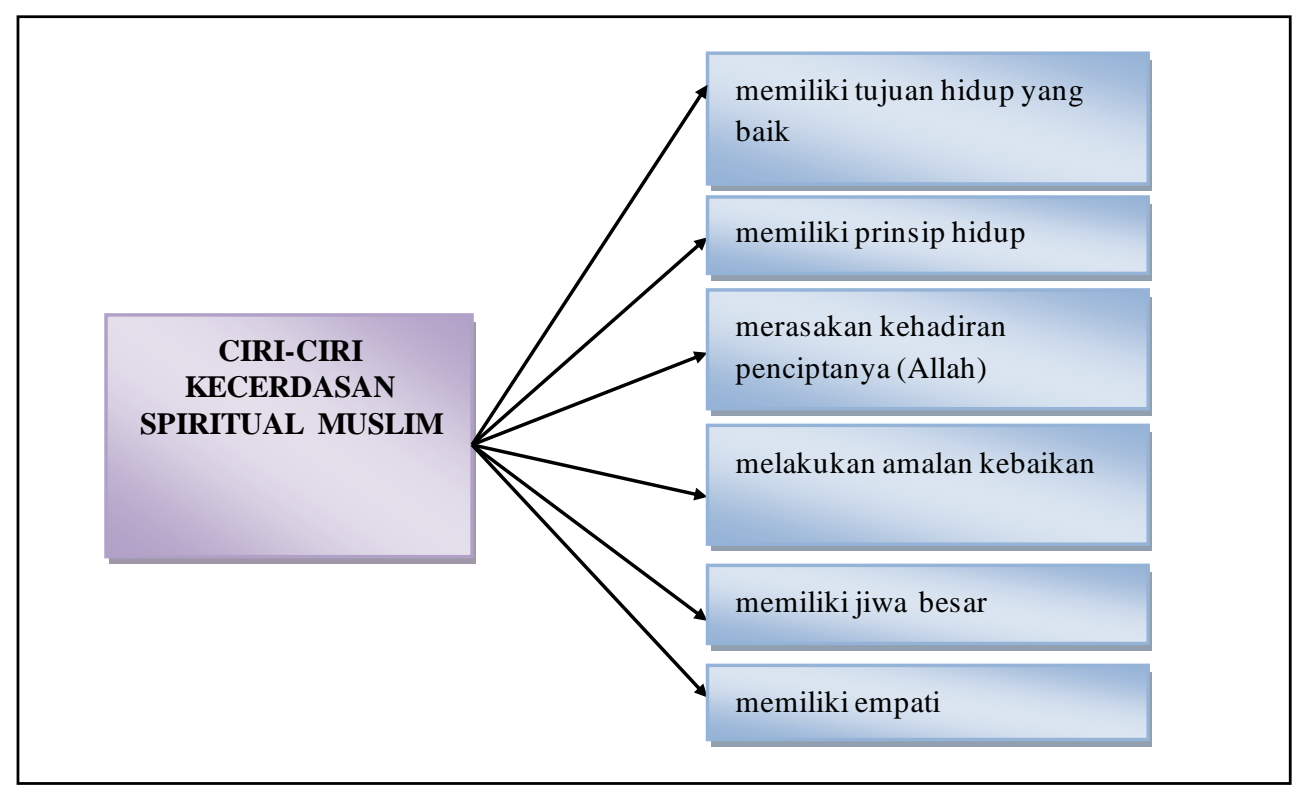

Sumber: Ashshidieqy (2018)

Berdasarkan definisi dan ciri-ciri kecerdasan spiritual yang dibincangkan di atas, definisi kecerdasan spiritual dalam kajian ini merujuk kepada persepsi pelajar tentang kefahaman mereka mengenai tujuan dan prinsip hidup, hubungan mereka dengan Tuhan, kepercayaan mereka pada Tuhan, hubungan mereka dengan orang lain, amalan keagamaan dan kebajikan yang dilakukan, dan jiwa dalaman mereka.

\section{Faktor Pendorong Kecerdasan Spiritual}

Banyak kajian lepas mengaitkan kecerdasan spiritual dengan kepercayaan, penghayatan dan amalan beragama. Dalam kajian Jurami (2012) misalnya, pendidikan agama yang memenuhi aspek kefahaman, pengamalan akidah, ibadah dan akhlak yang mantap dilihat memainkan peranan yang penting bagi meningkatkan tahap kesejahteraan spiritual atau nilai-nilai kerohanian individu yang beragama Islam. Shafi'e (2014) pula mendapati penghayatan dan amalan gaya hidup yang berlandaskan agama juga boleh meningkatkan kecerdasan spiritual umat Islam. Faktor-faktor lain berkaitan agama termasuk elemen tauhid (Ismail \& Anwar, 2011) dan amalan-amalan keagamaan seperti zikir (al-Baqarah (2): 152), doa (al-Baqarah (2): 186) dan sifat tawadhu' (an-Nahl (16): 53) (Hisham \& Sa'ari, 2009). Bagi masyarakat Islam, kekuatan spiritual adalah sangat penting bagi melindungi seseorang Muslim daripada terpesong akidah, terjebak dengan perbuatan yang boleh merosakkan jiwa atau menjadi manusia yang tidak berakhlak (Basah, 2015).

Dalam agama Hindu pula, nilai-nilai spiritual seorang penganut Hindu boleh ditingkatkan melalui aktiviti-aktiviti yang berkaitan dengan spiritual fizikal (Physical Spirituality), spiritual intelektual (Intellectual Spirituality), spiritual psikologi (Psychological Spirituality), spiritual sosial (Social Spirituality), spiritual emosi (Emotional Spirituality), spiritual etika (Ethical Spirituality), spiritual 
estetika (Aesthetical Spirituality), spiritual agama (Religious Spirituality), spiritual moden (Modern Spirituality), spiritual roh suci (Divine traits Spirituality), yoga dan meditasi (Srivastava, 2017).

Manakala bagi masyarakat beragama Buddha, tahap spiritualiti penganutnya bergantung kepada tiga faktor iaitu faktor demografi (umur, status sosioekonomi), konstruk psikologi (universal-diverse orientation dan fleksibiliti kognitif) dan amalan keagamaan (menyebarkan tentang Dhamma of Buddha, mendengar dan membincangkan tentang Dhamma dengan sami Buddha, menghadiri latihan meditasi, sembahyang, menjamu sami Buddha, mengekalkan Five Precepts dan meditasi) (Charoenchanaporn \& Madathil, 2015).

Rajah 6 menunjukkan ringkasan faktor kecerdasan spiritual mengikut fahaman agama berdasarkan perbincangan di atas.

Rajah 6: Faktor Pendorong Kecerdasan Spiritual Mengikut Fahaman Agama

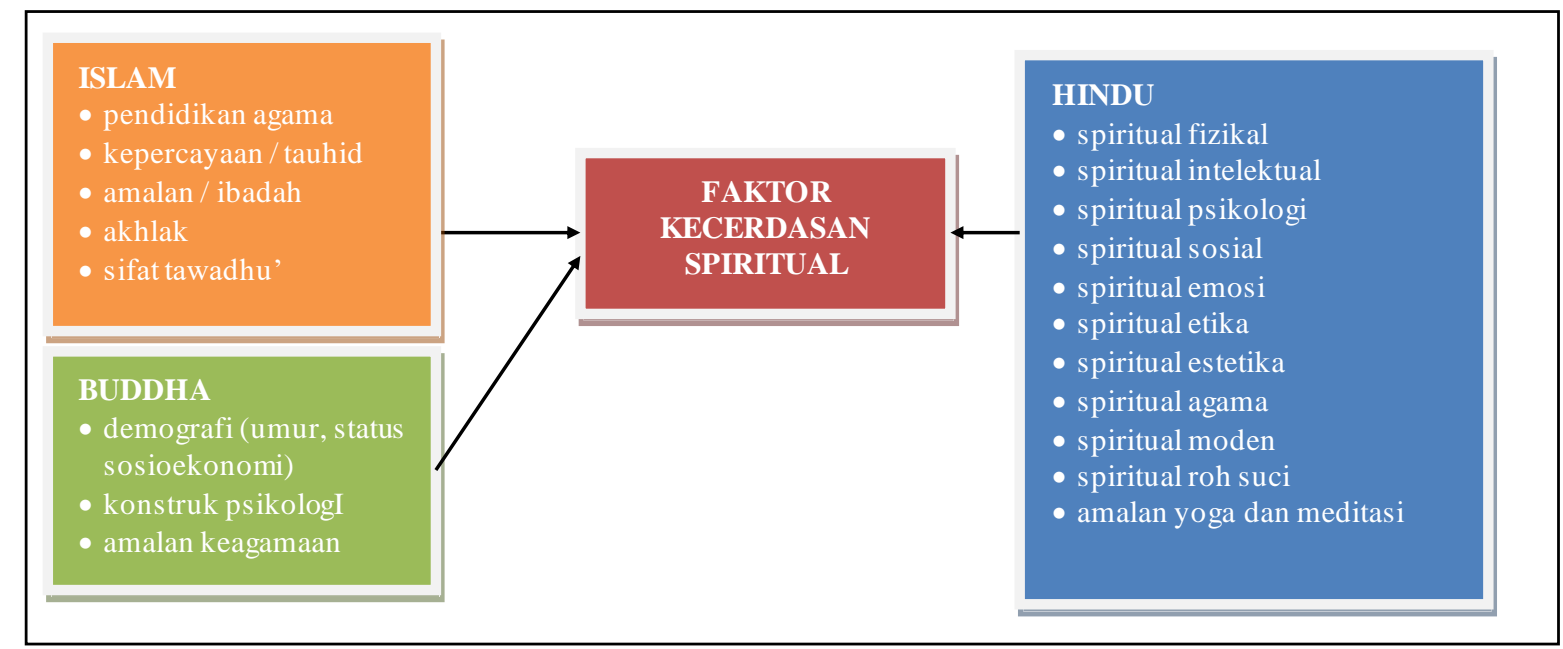

Dalam konteks pendidikan, antara faktor yang boleh meningkatkan kecerdasan spiritual di kalangan pelajar termasuk hubungan pelajar dengan rakan dan pensyarah, amalan kebajikan, persekitaran pembelajaran yang positif dan amalan muhasabah diri (Vaughan, 2002; Nasel, 2004). Kesemua faktor ini didapati mampu membantu pelajar membentuk tingkah laku yang positif (VonDras et al., 2007; Christopher \& James, 2011), meningkatkan keyakinan diri (Rohani, 2016), mengelak daripada terlibat dalam masalah salah laku atau masalah moral (Norazwa, 2013) dan meningkatkan kualiti kepimpinan dalam diri (Azam et al., 2012; Reave, 2005; Burke, 2006; Faisal, 2007; Amram, 2009).

\section{Kecerdasan Spiritual - Kebahagiaan Hidup}

Sorotan kajian telah menemukan banyak bukti empirikal yang mengaitkan kecerdasan spiritual dengan kebahagiaan hidup. Kajian yang dijalankan oleh Jalilian et al. (2017) ke atas 277 orang pelajar Kermanshah University of Medical Sciences mendapati bahawa terdapat hubungan yang positif dan signifikan antara kesihatan spiritual dan kebahagiaan hidup di kalangan pelajar $(\mathrm{r}=0.51, \mathrm{p}<.001)$. Francis et al. (2015) pula dalam kajiannya ke atas penganut wanita beragama Yahudi di Israel membuktikan bahawa kebahagiaan hidup mempunyai hubungan yang signifikan dengan sikap beragama (religious attitudes). Begitu juga dengan kajian oleh Tekke et al. (2018), Salehi et al. (2011) dan Abdel-Khalek (2012) di mana terdapat korelasi antara pegangan agama dan kebahagiaan hidup.

Kajian yang dijalankan oleh sarjana-sarjana Barat turut menunjukkan bahawa kecerdasan spiritual boleh meningkatkan kemampuan individu untuk melahirkan emosi yang positif (Kim-Prieto \& Diener, 2009; Loewenthal, 2009) dan berdepan dengan tekanan dan cabaran (Fischer et al., 2010). Sebagai contoh, dari perspektif spiritual, orang yang alim dilihat lebih sabar dan tenang apabila berdepan dengan masalah dan mudah menerima hakikat takdir yang telah ditentukan untuk hidup mereka. Selain itu, kecerdasan spiritual mampu menerapkan nilai-nilai murni (bersyukur, mengambil berat dan bersedekah) (McCullough et al., 2002) dan membantu dalam berinteraksi sosial dengan orang lain 
(Jung, 2014). Kesemua ini merupakan elemen-elemen yang penting dalam menentukan kesejahteraan dan kebahagiaan hidup seseorang.

Walau bagaimanapun, sorotan kajian lepas mendapati masih kurang kajian yang dilakukan untuk mengenalpasti sejauh mana dan bagaimana kecerdasan spiritual boleh mempengaruhi kebahagiaan hidup dalam konteks pelajar universiti di Malaysia. Oleh itu, model kebahagiaan hidup yang dibangunkan dalam kajian ini turut mengambil kira pengaruh kecerdasan spiritual dalam menentukan tahap kebahagiaan hidup sepanjang pengajian pelajar di universiti.

\section{Demografi - Kebahagiaan Hidup}

Faktor demografi seperti jantina dan umur juga dilihat boleh mempengaruhi kebahagiaan hidup seperti yang dibuktikan oleh Hill (2015) dalam kajiannya ke atas 71 orang belia di Dublin. Responden wanita dilihat mempunyai tahap kebahagiaan yang lebih tinggi berbanding responden lelaki. Kajian beliau juga menunjukkan bahawa umur adalah prediktor utama kepada kebahagiaan subjektif $(\beta=.47)$. Begitu juga dengan Tabbodi et al. (2015) yang mendapati pelajar wanita mempunyai tahap kebahagiaan hidup dan prestasi akademik yang lebih tinggi daripada pelajar lelaki. Walaubagaimanapun, Turashvili dan Japaridze (2012) dalam kajian mereka ke atas pelajar universiti di Georgia dan Wilcox dan Nordstokke (2019) dalam kajian mereka ke atas 66 orang pelajar Tahun Pertama University of Calgary mendapati tiada perbezaan yang signifikan antara tahap kebahagiaan hidup pelajar berdasarkan jantina.

Sorotan literatur mendapati kebanyakan kajian penyelidik tempatan yang mengambil kira faktor demografi lebih banyak tertumpu kepada kajian kesihatan mental (Islam et al. 2018; Hoo, 2008; Desa \& Sulaiman, 2004). Dengan erti kata lain, kajian mengenai pengaruh faktor demografi tersebut terhadap kebahagiaan hidup pelajar masih belum diterokai sepenuhnya. Oleh itu, model kebahagiaan hidup yang dibangunkan dalam kajian ini turut bertujuan untuk mengenalpasti bagaimana faktor demografi seperti jantina, tahun pengajian dan latar belakang agama boleh mempengaruhi kebahagiaan hidup pelajar di universiti di Malaysia.

\section{Teori-Teori Kajian}

\section{Teori Psikologi Positif Seligman (2003)}

Teori ini dibangunkan oleh Martin E. P. Seligman pada tahun 1998 untuk menyembuhkan penyakit mental, membantu semua orang untuk hidup dengan lebih produktif dan bermakna, dan mengenal pasti serta memelihara bakat atau potensi manusia.

Rajah 7: Teori Psikologi Positif Seligman (2003)

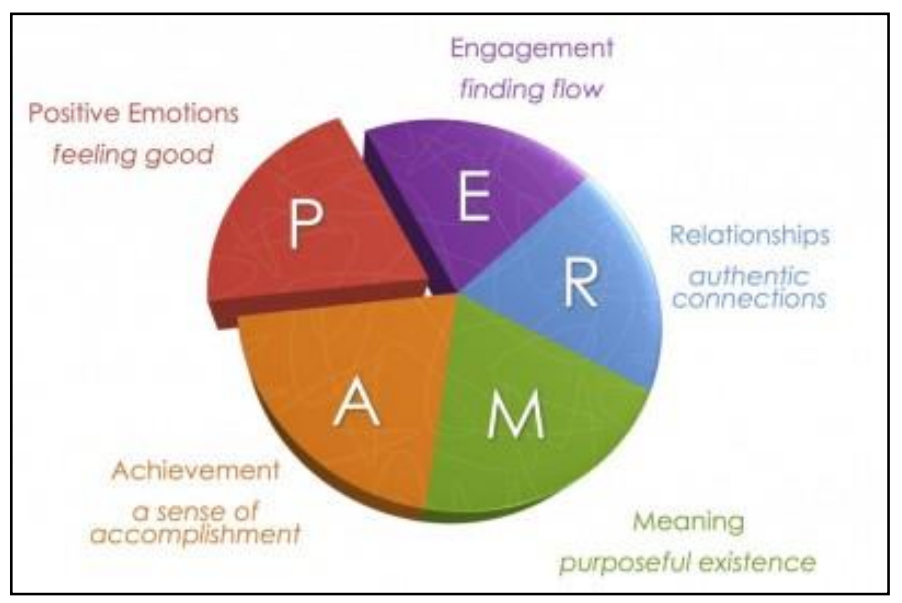


Menurut teori ini, terdapat lima elemen optimisme untuk seseorang membangunkan kekuatan positif dalam dirinya iaitu positive emotions (emosi positif), engagement(penglibatan), relationships (hubungan), meaning (makna) dan accomplishments (pencapaian) seperti yang ditunjukkan dalam Rajah 7 di bawah.

Dalam konteks kajian, teori ini akan digunakan dalam model kebahagiaan hidup pelajar untuk menerangkan bagaimana kesihatan mental boleh mempengaruhi kebahagiaan hidup daripada aspek emosi, fokus pembelajaran, hubungan dengan rakan dan tenaga pengajar, dan pencapaian akademik.

\section{Teori Kecerdasan Spiritual Amram (2008)}

Menurut teori ini, terdapat lima aspek utama kecerdasan spiritual berdasarkan model Amram (2008) iaitu Kesedaran (Consciousness), Kelembutan (Grace), Makna (Meaning), Menjangkaui/Transenden (Transcendence) dan Kebenaran (Truth) (rujuk Rajah 8).

Aspek 'Kesedaran' merujuk kepada keupayaan individu untuk membangunkan kesedaran dalam diri mengenai hal-hal kerohanian seperti kewujudan Tuhan. Manakala aspek 'Kelembutan' merupakan suatu kebolehan seseorang untuk memaafkan orang lain, mengungkap rasa terima kasih, merendah diri dan menunjukkan rasa cinta atau kasih sayang kepada orang lain. Aspek 'Makna' merujuk kepada keupayaan sesorang untuk memahami tujuan dan maksud kehidupan. Aspek 'Menjangkaui/Transenden' merupakan suatu kemampuan individu untuk mencapai pengalaman spiritual dan berhubung dengan perkara-perkara ghaib dan mistik manakala aspek 'Kebenaran' pula merujuk kepada keupayaan seseorang untuk mengamalkan gaya hidup yang bermoral berlandaskan prinsip dan kepercayaan agama.

Rajah 8: Model Kecerdasan Spiritual Amram (2008)

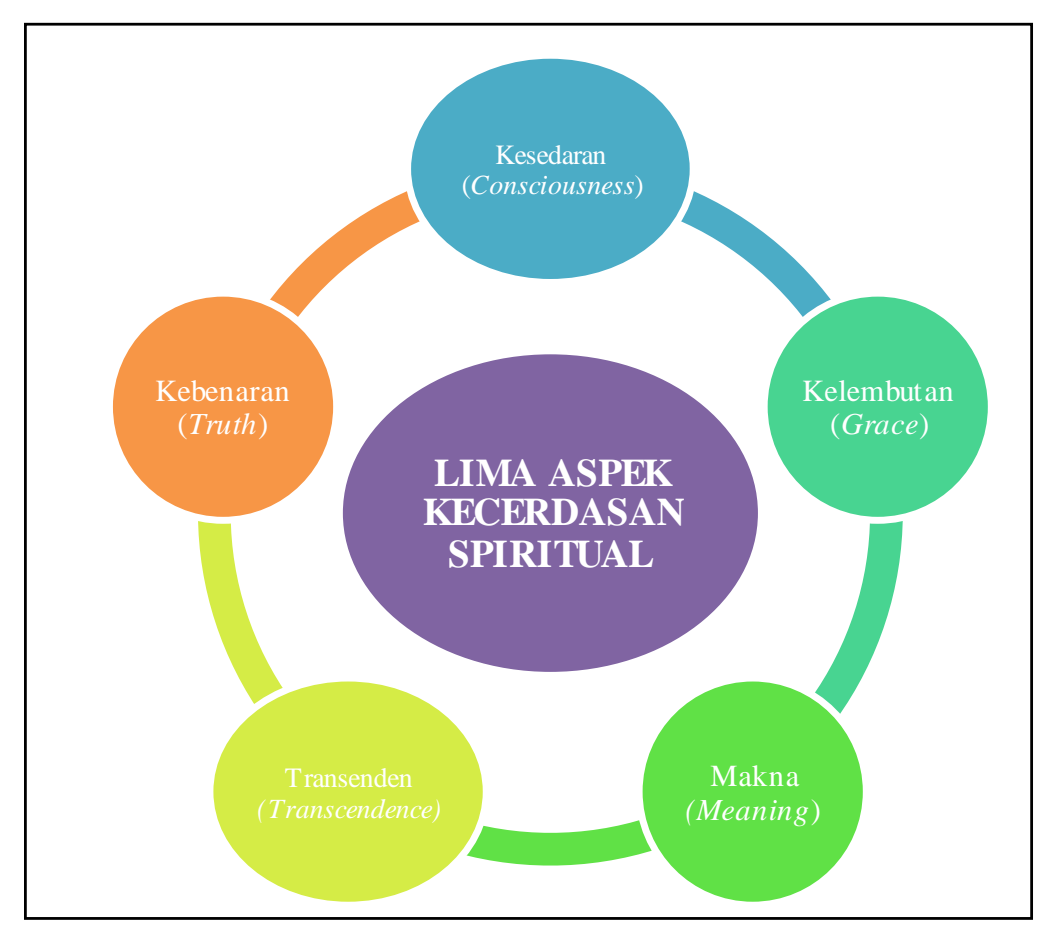

Lima aspek spiritual yang dinyatakan mampu meningkatkan fungsi dan kesejahteraan hidup seseorang dengan memberikan keupayaan untuk menggunakan pertimbangan yang sewajarnya dalam melakukan sesuatu, menyelesaikan masalah atau berhubung dengan orang lain, selaras dengan tuntutan moral dan agama walaupun ketika berada dalam keadaan kesusahan atau kepayahan. Selain itu, Amram (2009) berpendapat bahawa kecerdasan spiritual membolehkan seseorang lebih mempunyai kesedaran tentang diri sendiri (self-awareness), mempunyai kebijaksanaan (wisdom), memahami makna sebenar tujuan 
DOI: https://doi.org/10.47405/mjssh.v5i11.525

dihidupkan (sense of meaning), memiliki kasih sayang (compassion), memupuk hubungan positif dengan orang lain (connectedness) dan berperikemanusiaan (humanization).

Rajah 9: Impak Kecerdasan Spiritual

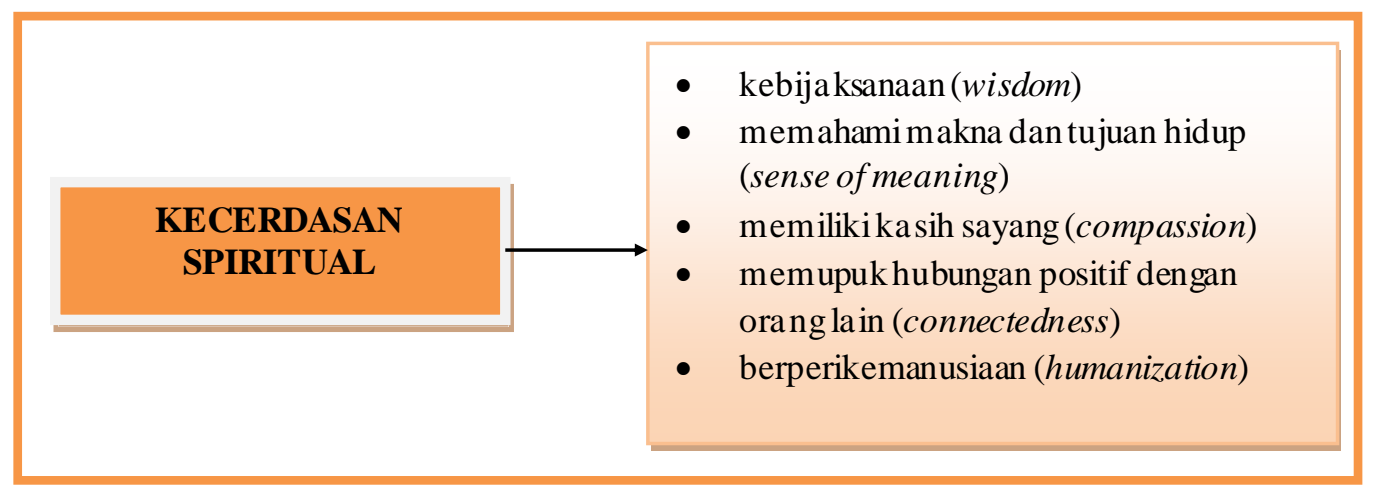

Berdasarkan kepada perbincangan di atas, teori ini akan digunakan dalam model kebahagiaan hidup pelajar untuk menerangkan bagaimana kecerdasan spiritual boleh mempengaruhi kebahagiaan hidup daripada aspek hubungan dengan keluarga, rakan dan tenaga pengajar, pengurusan masa, keharmonian persekitaran, pegangan agama, kepuasan pembelajaran dan pencapaian akademik pelajar.

\section{Teori Kesejahteraan Subjektif Diener (1984)}

Menurut Ed Diener (1984), kesejahteraan subjektif (subjective well-being) ialah persepsi seseorang terhadap pengalaman hidupnya, yang terdiri dari evaluasi kognitif dan afeksi terhadap hidup dan merepresentasikan dalam kesejahteraan psikologis. Perspektif teori ini menganggap bahawa individulah yang menentukan positif atau negatif sesuatu peristiwa atau kejadian yang berlaku itu. Untuk meningkatkan kesejahteraan subjektif, teori ini beranggapan perlunya mengubah persepsi, pandangan atau sikap terhadap sesuatu perkara. Rajah 10 menunjukkan bagaimana faktor kognitif, afektif dan kontekstual mempengaruhi kesejahteraan hidup dalam aspek kepuasan dan emosi menurut teori ini.

Rajah 10: Teori Kesejahteraan Subjektif Diener (1984)

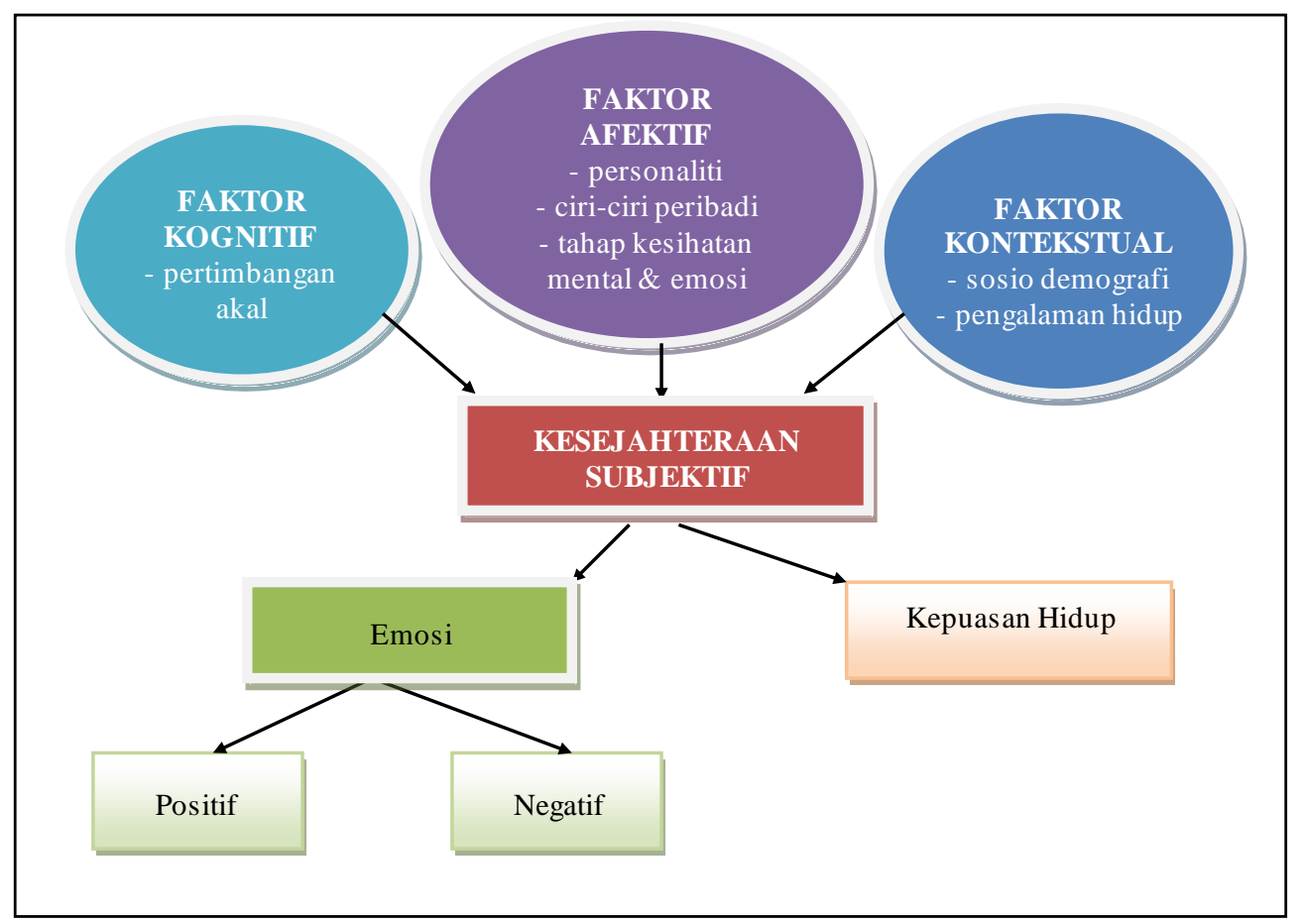


DOI: https://doi.org/10.47405/mjssh.v5i11.525

Kajian ini akan menggunakan teori ini untuk menilai tahap kebahagiaan hidup iaitu berdasarkan kepada penafsiran pelajar mengenai kualiti kehidupan mereka. Teori ini juga akan digunakan untuk mengkaji hubungan antara kesihatan mental, kecerdasan spiritual dengan kebahagiaan hidup. Teori ini mencadangkan bahawa pelajar yang mempunyai kesihatan mental yang baik dan tahap spiritual yang tinggi akan berfungsi dengan lebih baik dalam pengajian dan seterusnya akan mempunyai tahap kepuasan yang lebih tinggi terhadap kehidupannya sebagai pelajar dan prestasi akademiknya di universiti, walaupun terpaksa berdepan dengan pelbagai masalah dan cabaran.

\section{Model Kebahagiaan Hidup Pelajar}

Berdasarkan kepada sorotan kajian dan teori-teori yang telah dibincangkan di atas, dapat dirumuskan bahawa kebahagiaan hidup memainkan peranan yang penting dalam menentukan prestasi akademik pelajar. Kebahagiaan hidup pelajar juga boleh dipengaruhi oleh faktor kesihatan mental dan kecerdasan spiritual serta berbeza mengikut demografi setiap individu pelajar seperti jantina, tahun pengajian dan latar belakang agama.

Oleh itu, model kebahagiaan hidup yang dibangunkan dalam kajian ini adalah seperti yang ditunjukkan di dalam Rajah 11 di bawah.

\section{Rajah 11: Kerangka kajian}

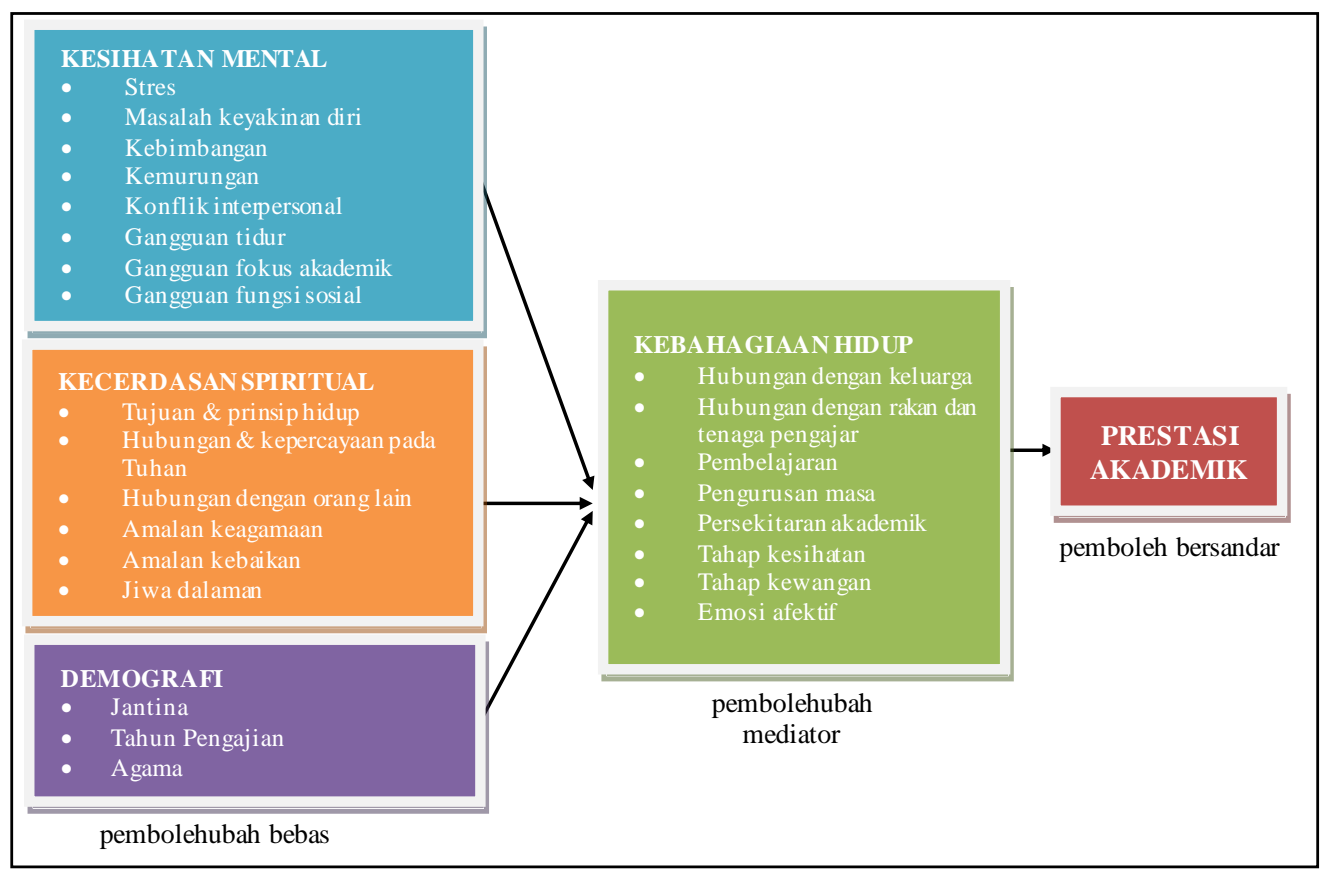

\section{Kesimpulan}

Artikel ini bertujuan untuk membangunkan sebuah model kebahagiaan hidup pelajar daripada aspek kesihatan mental, kecerdasan spiritual dan demografi. Model yang dibangunkan boleh digunakan untuk mengkaji bagaimana faktor-faktor ini boleh mempengaruhi tahap kebahagiaan hidup dan prestasi akademik pelajar dalam konteks universiti di Malaysia. Model ini juga berpotensi untuk dijadikan rujukan bagi pihak pengurusan universiti dalam merancang strategi dan program-program yang bersesuaian serta boleh memenuhi keperluan mental dan spiritual pelajar. 


\section{Rujukan}

Abdel-Khalek, A. M. (2012). Associations between religiosity, mental health, and subjective wellbeing among Arabic samples from Egypt and Kuwait. Mental Health, Religion and Culture, 15, 741-758.

Abdel-Khalek. A. M. (2006). Happiness, health, and religiosity: Significant relations. Mental Health, Religion \& Culture, 9(1), 85-97.

Adams, T. \& Moore, M. (2007) High-risk health and credit behavior among 18- to 25-yearold college students. Journal of American College Health, 56, 101-108.

Aghili, M., Mohamadi. N., \& Ghorbani, L. (2012). Evaluating the relationship between mental health and happiness in Iranian athletes. Journal of Basic and Applied Scientific Research, 2(3), 2494 2497.

Albuquerque, I., Lima, M., Matos, M., \& Figueiredo, C. (2013). The interplay among levels of personality: The mediator effect of personal projects between the big five and subjective wellbeing. Journal of Happiness Studies, 14(1), 235-250.

Amram, J. Y. (2009). The contribution of emotional and spiritual intelligences to effective business leadership. Institute of Transpersonal Psychology.

Ashshidieqy, H. (2018). Hubungan kecerdasan spiritual terhadap prestasi belajar siswa. Jurnal Penelitian dan Pengukuran Psikologi, 7(2), 70-76.

Azam, M. N. D., Mansor, M. \& Yaacob, S. N. (2012). Kecerdasan spiritual dan cara gaya kepimpinan dalam kalangan pemimpin remaja di Malaysia. Malaysian Journal of Youth Studies, 7, 10-22.

Basah, N. K. (2015). Pendekatan Spiritual Islam dalam menangani gejala remaja hamil luar nikah di sekolah harapan negeri Melaka. Disertasi Ijazah Sarjana Pengajian Islam, Universiti Kebangsaan Malaysia.

Borgonovi, F. (2015, April). Do teacher-student relations affect students' well-being at school? PISA in Focus. Dipetik daripada URL: http://www.oecd.org/pisa/pisaproducts/pisainfocus/PIF-50\%28eng\%29FINAL.pdf

Burke, R. (2006). Leadership and spirituality. Foresight, 8, 6, 14-25.

Byrk, A. S., \& Driscoll, M. E. (1998). The school as community: Theoretical foundation, contextual influences, and consequences for teachers and students. Madison, WI: National Center for Effective Secondary Schools.

Charoenchanaporn, P. \& Madathil, J. (2015). Exploration of Factors Influencing Spiritual Intelligence among Theravada Buddhists in Bangkok. Scholar: Human Sciences, 7(1), 155-171.

Christoper, A. S., \& James, M. D. (2011). Student spirituality and school counselling: Issues, opportunities and challenges. Counselling and Values, 55, 130-148.

Desa, A. \& Sulaiman, W. S. W. (2004). Academic stress and reactions to stressors among UKM students. Proceedings International Conference On Social Sciences and Humanities, 14-16 Disember 2004, Bangi, ms. 46-53.

Diener, E. (1984). Subjective well-being. Psychological Bulletin, 95, 542-575.

Diener, E. D., Lucas, R., Schimmack, U., \& Helliwell, J. (2009). Well-being for public policy. New York: Oxford University Press.

Diener, E., Oishi, S., \& Lucas, R. E. (2000). Personality, culture, and subjective well-being: emotional and cognitive evaluations of life. Annu. Rev. Psychol., 54, 403-425.

Ebadi, B. N., Hosseini, M. A., Rahgoi, A., Fallahi Khoshknab, M. \&, Biglarian, A. (2016). The relationship between spiritual health and happiness among nursing students. J Nurs Educ, 5, 2330 .

Eddington, N. \& Shuman, R. (2005). Subjective Well-Being. Continuing Psychology Education.

Faisal, R. F. (2007). The influence of emotional quotient and spiritual quotient with transformational leadership among managers in Universiti Utara Malaysia. Kertas Kerja. Universitas Andalas.

Fisher, J. (2010). Development and application of a spiritual well-being questionnaire called SHALOM. Religions, 1(1), 105-121.

Francis, L.J., Fisher, J.W. \& Annis, J. (2015). Spiritual well-being and psychological type: A study among visitors to a medieval cathedral in Wales. Ment Health Relig Cult, 18, 675-92.

Hamid, S. A. \& Rhouse, S. M. (2005). Punca tekanan pelajar di universiti: Satu perbandingan antara gender. Prasidang Persidangan Psikologi Malaysia 2005, 30 Julai - 2 Ogos 2005, Hotel Promenade, Kota Kinabalu. 
Hassanzadeh, R. \& Mahdinejad, G. (2013). Relationship between happiness and academic motivation: A case of university students. Journal of Elementary Education, 23(1), 53-65.

Hefner, J. \& Eisenberg, D. (2009). Social support and mental health among college students. American Journal of Orthopsychiatry, 79, 491-499.

Hill, E. (2015). The Relationship between Self-Esteem, Subjective Happiness and Overall Life Satisfaction. Disertasi untuk Ijazah Sarjana Muda Psikologi, National College of Ireland.

Hisham, A. \& Sa'ari, C. Z. (2009). Terapi Solat dalam Menangani Penyakit Gelisah (Anxiety) menurut Perspektif Psikoterapi Islam. Jurnal Usuluddin, 29(1), 1-45.

Hoo, C. L. (2008). Analysis of mental health profail among Universiti Malaysia Sabah. Tesis diterbitkan untuk pengajian Ijazah Sarjana Muda Sains, Universiti Malaysia Sabah.

Huebner, S. (2010). Students and their schooling: Does happiness matter? NASP Communique, 39(2). Dipetik daripada URL: http://www.nasponline.org/publications/cq/39/2/HappinessMatter.aspx

Hyun, J. K., Quinn, B. C., Madon, T. \& Lustig, S. (2006). Graduate student mental health: needs assessment and utilization of counselling services. Journal of College Student Development, 47(3), 247-266.

Islam, M. A., Wah, Y. L., Wen, T. T., Choo, W. Y. \& Abdullah, A. (2018). Factors Associated with Depression among University Students in Malaysia: A Cross-sectional Study, dalam The 2nd International Meeting of Public Health 2016 with theme "Public Health Perspective of Sustainable Development Goals: The Challenges and Opportunities in Asia-Pacific Region”, KnE Life Sciences, 415-427. 10.18502/kls.v4i4.2302

Ismail, K. \& Anwar, K. (2011). Psikologi Islam: Suatu Pendekatan Psikometrik Remaja Berisiko (Islamic Psychology: An Approach To Psychometric For At-Risk Adolescence). Journal of Social Sciences \& Humanities, 6(1), 77-89.

Ismail, K. H., Anwar, K. \& Hamsan, H. H. (2010). Analisis Kecenderungan Penyalahgunaan Bahan dan Faktor Keagamaan: Kajian Kes terhadap Belia di sebuah IPTA. Malaysia Journal Of Youth Studies, 3, 225-236.

Jalilian, N., Ziapour, A., Mokari, Z. \& Kianipour, N. (2017). A study of the relationship between the components of spiritual health and happiness of students at Kermanshah University of Medical Sciences in 2016. Ann Trop Med Public Health, 10, 1010-1014.

Jamali, T. \& Abasi, R. (2013). The study of relationshipbetween religious orientation and happiness in students of Payam Noor University. Tehran: The International Congress on Religious Culture and Thought.

Jones, V. (2015, March). Because I'm happy: An intriguing study notes a correlation between a student's level of happiness and GPA. Usable Knowledge. Dipetik daripada URL: https://www.gse.harvard.edu/news/uk/15/03/becausei\%E2\%80\%99mhappy

Jung, J. H. (2014). Religious attendance, stress, and happiness in South Korea: Do gender and religious affiliation matter? Social Indicators Research, 118(3), 1125-1145.

Jurami, S. K. (2012). Pengamalan ajaran Islam dalam kalangan pelajar melalui kursus pendidikan Islam di Politeknik Ungku Omar, Ipoh. Disertasi Ijazah Sarjana Pengajian Islam, Universiti Kebangsaan Malaysia.

Kamkary, K., \& Shokrzady, S. (2012). Investigating relation between happiness and mental health feel in Tehran youth people. European Journal of Experimental Biology, 2(5), 1880-1886.

Kim-Prieto, C., \& Diener, E. (2009). Religion as a source of variation in the experience of positive and negative emotions. Journal of Positive Psychology, 4(6), 447-460.

Kirkpatrick, B. \& Wanic, R. (2015). Personality and Happiness. Tesis Sarjana Muda, University of San Diego.

Kurniawati, E. \& Abrori, L. (2005). Korelasi SQ dengan kinerja pada Karyawan pada Karyawan UIN Malang. Malang: Psikoislamika.

Lee, M. F. \& Syaid, S. (2018). Factors Contributing towards Malaysian Technical University (MTU) Students' Mental Health. Pertanika J. Soc. Sci. \& Hum. 25(S), $93-100$.

Loewenthal, K. (2009). Culture, Religion and Spirituality in Relation to Psychiatric Illness. 10.1007/978-1-4020-9018-9_7.

Lyubomirsky, S., King, L, \& Diener, E. (2005). The benefits of frequent positive affect: Does happiness lead to success? Psychological Bulletin, 131(6), 803-855.

McCullough, M. E., Emmons, R. A., \& Tsang, J. A. (2002). The grateful disposition: A conceptual and empirical topography. Journal of Personality and Social Psychology, 82(1), 112-127. 
Mostafai, A. (2012). The Comparison between athlete women and non-athlete women regarding to mental health and happiness. Annuals of Biological Research, 3 (5), 2144-2147.

Mozafarinia, F., Amin-Shokravi, F. \& Hydarnia, A. (2014). Relationship between spiritual health and happiness among students. J Health Educ Health Promot, 2, 97-107.

Nasel, D. D. (2004). Spiritual orientation in relation to spiritual intelligence: A consideration of traditional Christianity and New Age/individualistic spirituality. Tidak diterbitkan. Disertasi Doktor Falsafah, University of South Australia.

Norazwa, Y. K. (2013). The influence of emotional and spiritual intelligence on misconduct of secondary school students. Disertasi Sarjana, Universiti Teknologi Malaysia.

Pfeiffer, D. (2001). Academic and Environmental Stress among Undergraduate and Graduate College Students: A Literature Review. Menomonie: University of Wisconsin-Stout.

Reave, L. (2005). Spiritual values and practices related to leadership effectiveness. The Leadership Quarterly, 16, 655-687.

Rohani, C. H. (2016). Relationship between life stress, social resources, reactive skills and spiritual well-being with self-esteem of truant youth. Disertasi Doktor Falsafah, Universiti Sains Malaysia.

Rosidi, N. H. (2017). Akhlak remaja Melayu semakin meruncing. Dipetik daripada http://www.utusan.com.my/rencana/forum/akhlak-remaja-melayu-semakin-meruncing1.478633\#ixzz55UaETUS3

Salehi, M., Hajizad, M., \& Bagheri, H. (2011). The relation between religious notion with students' happiness and mental well-being. World Applied Sciences Journal, 14 (10), 1537-1540.

Samsudin, S. \& Tan, K. C. H. (2016). Hubungan Antara Tahap Kesihatan Mental dan Prestasi Pelajar Sarjana Muda: Satu Kajian di Universiti Utara Malaysia. Jurnal Sains Kesihatan Malaysia, 14(1), 11-16.

Schiller, L. \& Hinton, C. (2015). Happier students get higher grades in school, research says. Dalam Time. Dipetik daripada URL: http://time.com/3984782/happy-students-highgrades

Schimmack, U., \& Diener, E. (2003). Predictive validity of explicit and implicit self-esteem for subjective well-being. Journal of Research in Personality.

Seligman, L. D. \& Wuyek, L A. (2007). Correlates of separation anxiety symptoms among firstsemester college students: An exploratory study. The Journal of Psychology 141(2), 135-146.

Seligman, M.E.P. \& Royzman, E. (2003). Happiness: The three traditional theories. Dipetik daripada $\mathrm{URL}=$ http://www. authentichappiness. sas.upenn.edu/newsletters/authentichappiness/happiness

Senf, K., \& Liau, A. (2013). The effects of positive interventions on happiness and depressive symptoms, with an examination of personality as a moderator. Journal Of Happiness Studies, $14(2), 591-612$.

Shafi'e, S. Z. (2014). Gaya Hidup remaja dan Hubungannya dengan pengamalan Islam di Bandar Baru Permas Jaya, Johor Bahru. Disertasi Ijazah Sarjana Pengajian Islam, Universiti Kebangsaan Malaysia.

Shafiq, S., Naz, R. A., Ansar, M., Nasrulla, T., Bushra, M. \& Imam, S. (2015). Happiness as Related to Mental Health among University Students. International Journal of Humanities and Social Science, 5(9), 124-132.

Sherina, M. S., Rampal, L. \& Kaneson, N. (2003). Psychological sress among undergraduate Medical students. Medical Journal Malaysia, 59(2), 207-11.

Srivastava, P. M. (2017). Determinants of Spiritual Intelligence in Indian Scenario. International Journal of Research in Social Sciences, 7(11), 203-211.

Subandi, M. A. (2001). Menyoal Kecerdasan Spiritual. Pembentangan di seminar di Yogyakarta, 6 Jun 2001.

Tabbodi, M., Rahgozar, H. \& Makki Abadi, M. M. (2015). The Relationship between Happiness and Academic Achievements. European Online Journal of Natural and Social Sciences, 4(1).

Tak, K. C. (2009). Takat kebahagiaan dan harga kendiri orang Melayu. Disertasi M.A, Univesity Malaya.

Tak, K. C. (2017). Dimensi kebahagiaan golongan dewasa melayu. Disertasi untuk Fakulti Sastera dan Sains Sosial, Universiti Malaya, Kuala Lumpur.

Tekke, M., Francis, L. J. \& Robbins, M. (2018). Religious affect and personal happiness: A replication among Sunni students in Malaysia. Journal of Muslim Mental Health, 11(2), 3-15. 
Turashvili, T. \& Japaridze, M. (2012). Psychological well-being and its relation to academic performance of students in Georgian context. Problems Of Education In The 21st Century, 49, 73-80.

Uehara, T., Takeuchi, K., Kubota, F., Oshima, K. \& Ishikawa, O. (2010). Annual transition of major depressive episode in university students using a structured self-rating questionnaire. Asia-Pacific Psychiatry. 2, 99-104.

Vaughan, F. (2002). What is spiritual intelligence? Journal of Humanistic Psychology, 42(2), 16-33.

VonDras, D.D., Schmitt, R.R., \& Marx, D. (2007). Associations between aspects of spiritual wellbeing, alcohol use, and related social-cognitions in female college students. Journal of Religion and Health, 46(4), 500-515.

WHO (2001). Basic documents (43rd Ed). Geneva: World Health Organization.

WHO (2007). What is Mental Health? Online Q\&A. World Health Organization. Dipetik daripada URL: http://www.who.int/

Wilcox, G. \& Nordstokke, D. (2019). Predictors of University Student Satisfaction with Life, Academic Self-Efficacy, and Achievement in the First Year. Canadian Journal of Higher Education, 49(1), $104-124$.

Yahaya, A., Latif, J. S., Hashim, S. \& Boon, Y. (2005). Psikologi Sosial Alam Remaja. PTS Bentong.

Yusoff, M. S. B. (2010). The sensitivity, specificity and reliability of the Malay version 30-item General Health Questionnaire (GHQ) in detecting distressed medical students. Education in Medicine Journal, 2(1), e12-e21.

Yvonne, K., Zilanawala, A., Booker, C. \& Sacker, A. (2018). Social media use and adolescent mental health: findings from the UK Millennium Cohort Study. E-Clinical Medicine, 6, 59-68.

Zohar, D. \& Marshall, I. (2000). SQ: Connecting with our spiritual intelligence. New York: Bloomsbury Publishing.

Zulkefly, N. S. \& Baharudin, R. 2010. Using the 12-item General Health Questionnaire (GHQ-12) to assess the psychological health of Malaysian college students. Global Journal of Health Science, 2(1), 73-80.

Zulkifli, I. (2013). Happiness and Students' Performance in Quantitative Subjects - A Preliminary Study. Prosiding Book of ICEFMO, 2013, Malaysia Handbook on the Economic, Finance and Management Outlooks. 